\title{
Chemical Composition and Digestibility of Six Species of Legumes (Fabaceae)
}

Sosa-Montes, Eliseo ${ }^{1}$; Mendoza-Pedroza, Sergio lban ${ }^{2 *}$; Perpetuo Álvarez Vázquez ${ }^{3}$; Domínguez-Martínez Pablo Alfredo ${ }^{4}$; Ricardo-Barcena Gama², Salazar González Jessica Lorena ${ }^{5}$

\begin{abstract}
${ }^{1}$ Universidad Autónoma Chapingo, Departamento de Zootecnia. Chapingo, Estado de México. ${ }^{2}$ Colegio de Postgraduados, Campus Montecillo, Montecillo, Texcoco, Estado de México. ${ }^{3}$ Universidad Autónoma Agraria Antonio Narro-Unidad Saltillo, México. ${ }^{4}$ Instituto Nacional de Investigaciones Forestales, Agrícolas y Pecuarias. Campo Experimental Valle del Guadiana. Durango, México. ${ }^{5}$ Universidad Mesoamericana de Puebla, Plantel Sur. Totimehuacan. Puebla, Puebla. México.
\end{abstract}

*Corresponding Author: sergiomp@colpos.mx

\begin{abstract}
Objectives: To determine the chemical composition and in vitro digestibility of Acacia angustissima, Dalea spp., Desmodium spp., Leucaena leucocephala, Phaseolus vulgaris and Tephrosia vicioides (Fabaceae).

Design/Methodology/Approach: Crude protein (CP), neutral detergent fiber (NDF), acid detergent fiber (ADF), crude lignin (CL), cellulose (Cel), hemicellulose (Hcel), cellular content (CC) and in vitro dry matter digestibility (IVDMD) were determined. The design was completely random with three replicates. The variables were correlated by pairs and the means of the species were compared with the Tukey's test $(P<0.05)$.

Results: Dalea spp. had the highest crude protein (17.7\%), followed by A. angustissima (15.9\%) and L. leucocephala (14.1\%). A. angustissima (73.2\%), Dalea spp. (74.9\%) and P. vulgaris (77.5\%) showed the highest IVDMD. L. leucocephala, Tephrosia vicioides and Desmodium spp. showed the lowest values of CP (14.1, 11.8 and 12.3\%, respectively) and IVDMD (70.4, 70.2 and $64.9 \%$, respectively). Desmodium spp. showed high levels of NDF (59.2\%), ADF (41.4\%), CL (17.5\%), Cel (29.7\%) and Hcel (17.8\%) (P<0.05). The IVDMD showed positive correlation with $C C$ and negative correlations with NDF, CL, and Hcel $(\mathrm{P}<0.05)$
\end{abstract}

Study Limitations/Implications: Desmodium spp. showed high content of CL and low values of CP and IVDMD, therefore supplements should be added when used this legume in animal feed.

Findings/Conclusions: Dalea spp. showed low levels of lignin and high levels of protein and digestibility, making it possible to use it as feed for ruminants.

Keywords: Fabaceae, crude protein, neutral detergent fiber, in vitro digestibility. 


\section{INTRODUCTION}

Forages

are the main source of food

for livestock, they can grow naturally, be sown and established for direct grazing, and they can be acquired through manual or mechanical cutting (Santos et al., 2015). The challenge for livestock producers lies in improving production in order to cover the demand and conserve natural resources and the environment (Giraldo, 1999). An important factor in animal production is the composition and quality of the forages that make up the diet (Rojas et al., 2005). Therefore it is important to know the forage resources available in a specific region, in order to develop systems that are more sustainable and productive (Lascano and Ávila, 1991). Legumes have nutritional quality and are cultivated as a protein bank in strips or in association with grasses (Poaceae) (Hess and Lascano, 1997). Since they have a short growing cycle, they can be used as emergency crops of high quality (Reta et al., 2013). Moreover, forage Fabaceae are of better quality than grasses due to better digestibility, which is related to lower fiber content, and most of their digestible energy comes from soluble cell constituents, rather than from fiber (Buxton et al., 1996). Although Fabaceae have higher protein content, there is little information in the literature reviewed about its nutritional value to justify including it in a diet, as either a principal or secondary component, in order to improve its efficiency for use by livestock (González and Cáceres, 2002; García and Medina, 2006). The objective was to determine the chemical composition and in vitro digestibility of six Fabaceae forage species native to the state of Morelos, Mexico.

\section{MATERIALS AND METHODS}

Six species of the Fabaceae family were used, and they were collected during the same time of year in several municipalities in Morelos, Mexico. Leaves, stems and fruits (aerial part) were collected in order to carry out a botanical identification up to genus (Table 1).
The samples were dried at a constant weight in an oven at $55^{\circ} \mathrm{C}$, and then each sample was analyzed in triplicate in order to determine the crude protein (CP), ether extract (EE) and ash (Ash) content or proximate analysis (AOAC, 1990), and the Van Soest et al. (1991) analysis: neutral detergent fiber (NDF), acid detergent fiber (ADF), crude lignin (CL), cellulose (Cel), hemicellulose (Hcel), cellular content (CC) and in vitro dry matter digestibility (IVDMD) with the methodology described by Giraldo et al. (2007). The study was carried out in the Animal Nutrition Laboratory of the Animal Science Department, in Texcoco, Mexico.

The variables of chemical composition and IVDMD were subjected to an analysis of variance (ANOVA) with the completely randomized experimental design. The means were compared with the Tukey's test $(P<0.05)$. Also, a correlation analysis was carried out by pairs of variables $(P<0.05)$ using the SPSS (2011) software.

\section{RESULTS AND DISCUSSION}

The results are expressed in dry basis (Table 2 and 3). and Table 4 shows the correlation between pairs of variables studied. Desmodium spp. showed the lowest IVDMD, CP and CC. Low CP values are associated with low levels of CC, and low CC levels are associated with low IVDMD. Inversely, Dalea spp. showed the highest IVDMD associated with elevated CP content. Acacia angustissima showed similar IVDMD values as Dalea spp., and slightly lower CP levels. Based on these results, it was inferred that with higher CP content there is higher IVDMD. These results can be explained by the following positive correlations: IVDMD vs CC and CC vs CP (Table 4). The positive correlation (0.96) between IVDMD (65.3\%) and CP (22.5\%) has been demonstrated $(P<0.01)$ in vetch by Gezahagn et al. (2014).

Desmodium spp. showed higher content of all fibrous components (NDF, ADF, CL, Cel and Hcel; Table 2) and lower IVDMD (Table 3). Dalea spp. showed the lowest

\begin{tabular}{l|l|l}
\begin{tabular}{l} 
Table 1. Species and collection sites in the state of Morelos, Mexico. \\
\multicolumn{1}{c}{ Species }
\end{tabular} & \multicolumn{1}{c}{ Municipality } & \\
Acacia angustissima & Ticuman & Tlaltizapan-Yautepec Highway, $5 \mathrm{~km}$ from Ticuman. \\
\hline Dalea spp. & Tlalquiltenango & At $200 \mathrm{~m}$ from the community of San Pablo, Tlalquiltenango \\
\hline Desmodium spp. & Nepoapulco & Next to the bridge "El Vigía". \\
\hline Leucaena leucocephala & Tepoztlán & "El Puente" place, in the community of Santa Catarina, Tepoztlán \\
\hline Phaseolus vulgaris & Nepoapulco & Before the bridge "El Vigia", towards Mexico City. \\
\hline Tephrosia vicioides & Totolapan & Tlayacapan-Atlatlahuacan highway, after the deviation towards Mexico City \\
\hline
\end{tabular}




\begin{tabular}{|c|c|c|c|c|c|}
\hline \multirow{2}{*}{ Species } & \multicolumn{5}{|c|}{$\%$ Dry basis } \\
\hline & NDF & ADF & $\mathrm{CL}$ & Cel & Hcel \\
\hline Acacia angustissima & $42.9^{c}$ & $29.0^{c}$ & $15.6^{\mathrm{ab}}$ & $13.4^{\mathrm{b}}$ & $13.9^{b}$ \\
\hline Dalea spp. & $50.4^{b}$ & $41.3^{a}$ & $11.6^{\mathrm{C}}$ & $29.7^{a}$ & $9.1^{c}$ \\
\hline Desmodium spp. & $59.2^{a}$ & $41.4^{a}$ & $17.5^{a}$ & $29.7^{a}$ & $17.8^{a}$ \\
\hline Leucaena leucocephala & $50.5^{b}$ & $30.9^{c}$ & $18.8^{a}$ & $12.0^{\mathrm{b}}$ & $19.6^{a}$ \\
\hline Phaseolus vulgaris & $49.5^{b}$ & $38.1^{b}$ & $12.7 b^{c}$ & $25.4^{a}$ & $11.4^{\mathrm{C}}$ \\
\hline Tephrosia vicioides & $59.0^{a}$ & $40.0 a^{b}$ & $13.4 b^{c}$ & $26.6^{a}$ & $19.0^{a}$ \\
\hline Standard error of mean & 1.38 & 1.22 & 0.69 & 1.96 & 0.98 \\
\hline
\end{tabular}

\begin{tabular}{|c|c|c|c|c|c|}
\hline \multirow{2}{*}{ Species } & \multicolumn{5}{|c|}{ \% Dry basis } \\
\hline & IVDMD & $\mathrm{CP}$ & $\mathrm{CC}$ & EE & Ash \\
\hline Acacia angustissima & $73.2^{a b}$ & $15.9^{b}$ & $57.1^{a}$ & $2.7^{d}$ & $4.2^{d}$ \\
\hline Dalea spp. & $74.9^{a b}$ & $17.7^{\mathrm{a}}$ & $49.6^{b}$ & $3.6^{b}$ & $6.7 \underline{a}$ \\
\hline Desmodium spp. & $64.9^{c}$ & $12.3^{\mathrm{d}}$ & $40.8^{c}$ & $3.0^{c}$ & $4.7^{c}$ \\
\hline Leucaena leucocephala & $70.4^{b}$ & $14.1^{\mathrm{C}}$ & $49.5^{b}$ & $4.2^{a}$ & $6.7 \underline{a}$ \\
\hline Phaseolus vulgaris & $77.5^{a}$ & $11.7^{d}$ & $50.5^{b}$ & $3.7^{b}$ & $6.0^{b}$ \\
\hline Tephrosia vicioides & $70.2^{b}$ & $11.8^{d}$ & $41.0^{c}$ & $2.8 c^{d}$ & $6.1^{b}$ \\
\hline Standard error of mean & 1.04 & 0.55 & 1.38 & 0.15 & 0.23 \\
\hline
\end{tabular}

by Ortíz-Domínguez et al. (2017) in pods of different Fabaceae (previously known as legumes) for IVDMD vs NDF (-0.848) and for IVDMD vs CL (-0.957).

Tephrosia vicioides showed similar NDF, ADF, CL, Cel and Hcel levels (Table 2) as L. leucocephala and its IVDMD values were also similar (Table 3). The elevated levels of IVDMD showed by P. vulgaris are probably due to its low values of $\mathrm{CL}$ and Hcel (Table 2). The negative correlations in Table 4 indicate that lower CL vs higher IVDMD (-0.601), and lower Hcel vs higher IVDMD (-0.713). At higher levels of NDF, there were high levels of ADF, Hcel or Cel. With higher levels of the fiber variables (NDF, CL or Hcel), there are lower values of IVDMD, CP or CC. Therefore, Desmodium spp., which resulted with high levels of NDF, ADF, CL, Cel and Hcel, produced the lowest values of IVDMD, CP and CC. At low values of $C L$ and $\mathrm{Hcel}$, there were high levels of IVDMD; therefore, Dalea spp., which produced low values of $\mathrm{CL}$ and Hcel, produced high levels of IVDMD. value of $\mathrm{CL}$ and Hcel (Table 2 and 3), associated with high levels of IVDMD. Acacia angustissima showed low amounts of NDF, ADF, Cel and Hcel, and higher IVDMD than Desmodium spp. This indicates a negative correlation between IVDMD and NDF, CL and Hcel (Table 4). These negative correlations by pairs $(P<0.05)$ between fibrous components and IVDMD were reported

\section{Comparison of CP and IVDMD values of this study with those from the literature}

Acacia angustissima (CP: 15.9\%, IVDMD: 73.2\%). Ncube et al. (2017) reported $23.4 \%$ of CP in A. angustissima. Aganga et al. (1997) found 12.52\%, 17.14\%, 13.67\% and $12.74 \%$ of CP for A. robusta, A. nigrescens, A. karoo, and $A$. rehmanniana, respectively. Castrejón et al. (2017)

\begin{tabular}{c|c|c|c|c|c|c}
\multicolumn{2}{c}{ Table 4. Significant correlations between the response variables. } \\
\hline
\end{tabular}

The non-fibrous components are IVDMD: in vitro dry matter digestibility, CP: crude protein, CC: cellular content, EE: ether extract, Ash: ashes. The fibrous components are NDF: neutral detergent fiber, ADF: acid detergent fiber, CL: crude lignin, Cel: cellulose, Hcel: hemicellulose. $\left(^{\star}\right)$ : $P<0.05,(* *): P<0.01$. 
reported $16.8 \%$ of CP and $64.3 \%$ of IVDMD for Acacia farnesiana. Goel et al. (2015) found IVDMD values between $56.9 \%$ and $65.7 \%$ for Acacia nilotica. OrtízDominguez et al. (2017) found IVDMD values of $44.5 \%$ for Acacia pennatula.

Dalea spp. (CP: 17.7\%, IVDMD: 74.9\%). Huang et al. (2015) reported $13.3 \%(N \times 6.25)$ of CP in Dalea purpurea, and Peng et al. (2020) reported $70.5 \%$ of IVDMD in Dalea purpurea.

Desmodium spp. (CP: 12.3\%, IVDMD: 64.9\%). Tessema and Baars (2006) reported CP values of $23.1 \%$ in Desmodium uncinatum, and Chamorro et al. (2005) reported an average of $76.4 \%$ of IVDMD in Desmodium barbatum.

Leucaena leucocephala (CP: 14.1\%, IVDMD: 70.4\%) Gutiérrez et al. (2005), found 25\% of CP in Leucaena leucocephala. Castrejón et al. (2017) reported 17.6\% of CP and $74.9 \%$ of IVDMD for Leucaena leucocephala in Paso del Toro, Veracruz, six weeks after regrowth. Ortíz-Domínguez et al. (2017) found $46.4 \%$ of IVDMD for Leucaena leucocephala.

Phaseolus vulgaris (CP: 11.7\%, IVDMD: 77.5\%). AlatorreHernández et al. (2018) found $11.7 \%$ of CP and $49.4 \%$ of IVDMD for Phaseolus acutifolius. Vojtišková and Kráčmar (2013), found $41.0 \%$ of IVDMD in Phaseolus vulgaris.

Tephrosia vicioides (CP: 11.8\%, IVDMD: 70.2\%). Ojo et al. (2012) reported $13.6 \%$ of CP for Tephrosia bracteolata 20 weeks after sowing, and Chamorro et al. (2005) reported $80.5 \%$ of IVDMD in Tephrosia cinerea, similar and superior when compared to the values reported in this study.

In general, the majority of the values of the variables in this study were $10 \%$ higher or lower than those in the literature consulted. For example, Tessema and Baars (2006) found values of NDF (46.50\%) and ADF (35.4\%) in Desmodium uncinatum, which are lower than those reported in this study (Table 2). For the Ash variable, Ncube et al. (2017) found values of $4.3 \%$ in Acacia angustissima, and Ojo et al. (2012) found values of $5.3 \%$ in Tephrosia bracteolata, similar to those in this study (Table 3). Ojo et al. (2012) reported $13.6 \%$ of $C L$ and $2.2 \%$ of $E E$ in Tephrosia bracteolata. García et al. (2008) reported ADF levels of $25.4 \%$ for Leucaena spp., while in this study 30.9\% was obtained (Table 2). In most cases the values of $C L$ and Ash in the present study were similar; those of EE, CP and NFD were lower, and ADF and IVDMD were higher than those reported in the literature for the same species of Fabaceae.

\section{CONCLUSIONS}

Dalea spp. was the best forage species. With Desmodium spp. high supplementation with protein and non-fibrous carbohydrates should be used; and with Dalea spp. supplementation could be less or none. For the rest of the species that were not in the extreme positions, moderate supplementation could be used.

\section{REFERENCES}

Aganga, A.A., Tsopito, C.M., \& Adogla-Besssa, T. (1997). Potencial alimenticio para los rumiantes de las especies de Acacia de Botswana. Archivos de Zootecnia. 47 (180): 659-668.

Alatorre-Hernández, E., Guerrero-Rodríguez. J.D., Olvera-Hernández, J.I., Aceves-Ruíz, E., Vaquera-Huerta, H., \& Vargas-López, S. (2018) Productividad, características fisicoquímicas y digestibilidad in vitro de leguminosas forrajeras en trópico seco de México. Revista Mexicana de Ciencias Pecuarias. 9(2): 296-315.

AOAC (1990). Methods of analysis of the association of official analytical chemists. (15th Ed.). Arlington. VA: Association of Official Analytical Chemists. 771 p.

Buxton, D.R., Mertens, D.R., \& Fisher, D.S. (1996). Forage quality and ruminant utilization. In: cool season grasses. Agronomy monograph. American Society of Agronomy. 1: 229-266.

González, E., \& Cáceres, O. (2002). Valor nutritivo de árboles, arbustos y otras plantas forrajeras para los rumiantes. Pastos y Forrajes 25 (1): 15-20

Castrejón, P.F.A., Corona, G.L., Rosales, M.R., Martínez, P.P., Lorenzana M.A.V., Arzate, V.L.G., et al. 2017. Características nutrimentales de gramíneas, leguminosas y algunas arbóreas forrajeras del trópico mexicano: fracciones de proteína (A, B1, B2, B3 y C), carbohidratos y digestibilidad in vitro. (1a Ed.). México: Facultad de Medicina Veterinaria y Zootecnia (UNAM). 172 p.

Chamorro, D., Carulla, J. E., \& Cuesta, P. (2005). Degradación microbiana in situ de tejidos foliares de gramíneas y leguminosas y su relación con indicadores de calidad nutricional. Ciencia y Tecnología Agropecuaria. 6(1): 100-116. Disponible en: https:// WWW.redalyc.org/articulo.oa? $i d=4499 / 449945018012$

García, D.E., \& Medina, M.G. (2006). Composición química metabolitos secundarios, valor nutritivo y aceptabilidad relativa de diez árboles forrajeros. Zootecnia Tropical. 24(3): 233-250. Recuperado el 17 de abril de 2020 de http://ve.scielo.org/scielo. php?script $=$ sci_arttext\&pid $=$ S0798-72692006000300004\&ln $\mathrm{g}=$ es\&tlng $=$ es

García, D., Wencomo, H., Medina, M., Cova, L., González, M., Pisan, P. Domínguez, C., \& Baldizán A. (2008). Variación interespecífica de la calidad nutricional de diecisiete accesiones de Leucaena. Avances en Investigación Agropecuaria. 12(1):67-80

Gutiérrez, O., Delgado, P., Oramas, A., \& Cairo, J. (2005). Consumo y digestibilidad de materia seca y nitrógeno total en vacas en pastoreo durante la época de lluvias, con bancos de proteína y sin ellos. Revista Cubana de Ciencia Agrícola. 39(4): 593-598. 
Gezahagn K., Getnet A., Alemayehu M. \& Fekede F. (2014). Forage nutritive values of vetch species and their accessions grown under nitosol and vertisol conditions in the central highlands of Ethiopia. Livestock Research for Rural Development. 26(1), Article 20. Retrieved April 17, 2020, from http://www.lrrd.org/ Irrd26/1/kebe26020.htm

Giraldo, V.L.A. (1999). Potencial de la arborea guácimo (Guazuma ulmifolia), como componente forrajero en sistemas silvopastoriles. Universidad Nacional de Colombia. Agroforestería para la Producción Animal en Latinoamérica. 1 201-215.

Giraldo, L.A., Gutiérrez, L.A., \& Rúa, C. (2007). Comparación de dos técnicas in vitro e in situ para estimar la digestibilidad verdadera en varios forrajes tropicales. Revista Colombiana de Ciencias Pecuarias. 20: 269-279.

Goel, G., Raghav, M., Beniwal, V., \& Puniya, A.K. (2015). Anaerobic degradation of tannins in Acacia nilotica pods by Enterococcus faecalis in co-culture with ruminal microbiota. Journal of General Applied Microbiology. 61(1): 31-33. DOI: 10.2323/ jgam. 61.31

Hess, D.H., \& Lascano, C.E. (1997). Comportamiento del consumo de forrajes por novillos en pasturas de gramínea sola y asociada con una leguminosa. Pasturas tropicales. 19 (2): 12-20.

Huang, Q.Q., Jin, L., Xu, Z., Barbieri, L.R., Acharya, S., Hu, T.M., Mcallister, T.A., Stanford, K. \& Wang, Y. (2015). Effects of purple prairie clover (Dalea purpurea Vent.) on feed intake, nutrient digestibility and faecal shedding of Escherichia coli O157: H7 in lambs. Animal Feed Science and Technology. 207: 5161. DOl: 10.1016/j.anifeedsci.2015.06.009DOI: 10.1016/j. anifeedsci.2015.06.009

Lascano, C.E., \& Avila P. (1991). Potencial de producción de leche en pasturas solas y asociadas con leguminosas adaptadas a suelos ácidos. Pasturas Tropicales. 13(3): 2-10.

Ncube, S., Halimani, T. E., Mwale, M., \& Saidi, P. T. (2017). Effect of Acacia angustissima leaf meal on the physiology of broiler intestines. Journal of Agricultural Science. 9(2): 53-62.

Ojo, V.O.A., Aina, A.B.J., Arigbede, O.M., Olanite, J.A., Amole, T.A., Anele Y.U., Dele, P.A., Adeoye, S.A., \& Idowu, O.J. (2012). EValuation of the agronomic performance and nutritive values of Tephrosia bracteolata Guill. \& Perr. and Gmelina arborea Roxb prunnings at different stages of growth. Journal of Agricultural Science and Environment. 12(2):15-25.

Ortíz-Domínguez, G., Ventura-Cordero, J., González-Pech, P., TorresAcosta, J.F.J., Capetillo-Leal, C.M., \& Sandoval-Castro, C.A. (2017). Nutritional value and in vitro digestibility of legume pods from seven trees species present in the tropical deciduous forest. Tropical and Subtropical Agroecosystems. 20: 505-510.

Peng K., Gresham, G.L., McAllister, T.A., Xu, Z., Iwaasa, A., Schellenberg, M., Chaves, A. V., \& Wang, Y. (2020). Effects of inclusion of purple prairie clover (Dalea purpurea Vent.) with native coolseason grasses on in vitro fermentation and in situ digestibility of mixed forages. Journal of Animal Science and Biotechnology. 11: 23 https://doi.org/10.1186/s40104-019-0418-6

Reta, S.D.G., Castellanos, G.P.C., Olague, R.J., Quiroga, G.H.M., Serrato, C.J.S., \& Gaytán, M.A. (2013). Potencial forrajero de cuatro especies leguminosas en el ciclo de verano en la Comarca Lagunera. Revista Mexicana de Ciencias Agrícolas 4 (5): 639671

Rojas, H.S., Olivares, P.J., Jiménez, G.R., \& Hernández, C.E. (2005) Manejo de praderas asociadas de gramineas y leguminosas para pastoreo en el trópico. Revista Electrónica de Veterinaria. 6: $1-19$

Santos, P.J., Castellón, J., \& Guharay, F. (2015). Manual de conservación de forrajes. Managua, Nicaragua. Managua, Nicaragua. Editorial Catholic Relief Services. 9-11 pp.

SPSS, Statistical Package for the Social Sciences. (2011). Institute. SPSS-X. User's Guide. Version 8, Chicago IL. USA.

Tessema, Z., \& Baars, R.M.T. (2006). Chemical composition, dry matter production and yield dynamics of tropical grasses mixed with perennial forage legumes. Tropical Grasslands. 40: 150 -156.

Van Soest, P.J., Roberton, J.B., \& Lewis, B.A. (1991). Methods for dietary fiber, neutral detergent fiber, and nonstarch polysaccharides in relation to animal nutrition. Journal of Dairy Science. 74(10): 3583-3597.

Vojtišková, P., \& Kráčmar, S. (2013). Crude protein, fibre and phytic acid in vitro digestibility of selected legume and buckwheat samples. Acta Universitatis Agriculturae et Silviculturae Mendelianae Brunensis. 61 (1): 227-232.

\section{$\Delta P$ \\ A Acoucrivioan}

